\title{
Prevalensi dan Identifikasi Protozoa Saluran Pencernaan pada Monyet Eekor Panjang di Pulau Nusa Penida
}

\section{(PREVALENCE AND IDENTIFICATION OF GASTROINTESTINAL PROTOZOA IN LONG- TAIL MONKEY IN NUSA PENIDA ISLAND)}

\author{
Anak Agung Wisnu Kusuma Putra ${ }^{1 *}$, I Nengah Wandia ${ }^{2}$, I Made Dwinata ${ }^{3}$ \\ ${ }^{1}$ Program Pendidikan Dokter Hewan, ${ }^{2}$ Laboratorium Anatomi dan Embriologi Veteriner; \\ Pusat Penelitian Satwa Primata, ${ }^{3}$ Laboratorium Parasitologi Veteriner, Fakultas Kedoteran \\ Hewan Universitas Udayana. Jl. PB. Sudirman, Denpasar, Bali. \\ *Email: kusuma.wisnu10@gmail.com
}

\begin{abstract}
ABSTRAK
Penelitian ini bertujuan untuk mengetahui jenis dan prevalensi protozoa yang menyerang saluran pencernaan pada monyet ekor panjang di pulau Nusa Penida. Penelitian ini merupakan penelitian observasional, dengan menggunakan 50 sampel feses yang diambil dari 10 - 15 feses pada lokasi secara acak. Feses diperiksa menggunakan metode konsentrasi pengapungan dengan Seng Sulfat $\left(\mathrm{Z}_{\mathrm{n}} \mathrm{SO}_{4}\right)$ $33,1 \%$. Pemeriksaan menggunakan mikroskop dengan pembesaran obyektif 40x dengan melihat morfologinya. Data yang diperoleh disajikan secara deskriptif meliputi jenis dan prevalensi protozoa saluran pencernaan pada monyet ekor panjang. Hasil penelitian menemukan terdapat sebanyak $40 \%$ infeksi protozoa saluran pencernaan pada monyet ekor panjang di Pulau Nusa Penida. Jenis protozoa yang menginfeksi terdiri dari Entamoeba sp. sebesar $40 \%$ dan Balantidium coli sebesar 32\%. Perlu dilakukan upaya pencegahan penyebaran penyakit protozoa, melalui edukasi higiene dan sanitasi kepada masyarakat.
\end{abstract}

Kata kunci: Prevalensi; protozoa; saluran pencernaan; monyet ekor panjang; Nusa Penida.

\begin{abstract}
This study aims to determine the type and prevalence of protozoa that infects the digestive tract in long-tailed monkeys on the island of Nusa Penida. This study was an observational study, using 50 faces samples taken from 10-15 stools at random locations. Stool was examined using a concentration of flotation method with Zinc Sulphate (ZnSO4) 33.1\%. Examination with a 40x microscope objective magnification to look at the morphology. The data obtained are presented descriptively including the type and prevalence of gastrointestinal protozoa in long-tailed monkeys. The study found that there were $40 \%$ of gastrointestinal protozoan infections in long-tailed monkeys on Nusa Penida Island. The type of infecting protozoa consists of Entamoeba sp. by $40 \%$ and Balantidium coli by $32 \%$. Efforts should be made to prevent the spread of protozoa, through hygiene and sanitation education to the community.
\end{abstract}

Keywords: Prevalence; protozoa; gastrointestinal; long-tailed monkeys; Nusa Penida.

\section{PENDAHULUAN}

Monyet ekor panjang (Macaca fascicularis) merupakan primata yang termasuk ke dalam family Cercopithecidae yang persebarannya sangat luas di Indonesia salah satunya di Bali. Persebaran yang luas disebabkan karena tingginya adaptasi terhadap perubahan lingkungan (Supriatna dan Wahyono. 2000).
Di pulau Bali, populasi monyet ekor panjang umumnya berada di kawasan pura dan sering dimanfaatkan sebagai objek wisata (Mahayuni et al., 2018). Monyet ekor panjang memiliki makna yang penting bagi masyarakat. Hal ini karena monyet ekor panjang memiliki nilai ekologi, estetika, rekreasi dan keilmuan (Nugraha, 2018). 
Turunnya populasi primata di alam bebas, sering terkait adanya protozoa yang merupakan salah satu penyakit penyebab diare yang sering dijumpai pada primata non-human (NHP). Studi yang dilakukan oleh Levecke et al. (2007), melaporkan prevalensi protozoa saluran pencernaan monyet dan kera di kebun binatang di Belgia dengan 910 sampel feses tercatat 44\% sampel terinfeksi Entamoeba sp., $41 \%$ terinfeksi Giardia dan $13 \%$ terinfeksi Balantidium coli. Menurut Yulfi (2006) faktor yang cukup berpengaruh terhadap prevalensi protozoa saluran pencernaan adalah kontaminasi pakan, yang dapat terjadi melalui air yang terkontaminasi, infected food handler, kontaminasi oleh lalat dan kecoa.

Eratnya interaksi antara satwa primata seperti salah satunya monyet ekor panjang (Macaca fascicularis) dan manusia pada kawasan dimaksud dapat menyebabkan sering terjadinya transmisi penyakit zoonosis antar satwa primata dan manusia Balantidium coli, Entamoeba hystolitica, Giardia sp merupakan protozoa yang bersifat zoonotik (Burgos-Rodriguez, 2011; Toft dan Eberhard, 2012; Joesoef, 2018). Sehingga pengendalian terhadap penyakit pada primata non-human yang disebabkan protozoa saluran pencernaan pada monyet ekor panjang di Nusa Penida, menjadi salah satu upaya pencegahan terjadinya penularan penyakit dari primata non-human ke manusia. Penelitian ini bertujuan untuk mengetahui jenis dan prevalensi protozoa yang menyerang saluran pencernaan pada monyet ekor panjang di pulau Nusa Penida.

\section{METODE PENELITIAN}

Penelitian ini merupakan penelitian observasional dengan jumlah sampel feses sebanyak 50 sampel. Penelitian dilakukan untuk mengidentifikasi, dan mengukur prevalensi protozoa pada monyet di pulau Nusa Penida, Bali. Fases diambil sebanyak 10 - 15 sampel secara acak dari 4 lokasi yaitu di Pura Puncak Mundi, Pura Goa Giri Putri, Pura Puser Sahab dan Pura Paluang di daerah pulau Nusa Penida, Bali. Feses monyet segar diambil dari tanah dimasukkan ke dalam tabung feses dan diberi Kalium Bikromat $\left(\mathrm{K}_{2} \mathrm{Cr}_{2} \mathrm{O}_{7}\right)$. Sampel yang telah terkumpul dibawa ke laboratoriam untuk dilakukan pemeriksaan.

Feses diperiksa menggunakan metode kosentrasi pengapungan dengan Seng Sulfat $\left(\mathrm{Z}_{\mathrm{n}} \mathrm{SO}_{4}\right) 33,1 \%$. Pertama-tama, feses sebesar biji kemiri atau kurang lebih seberat 3 gram dimasukan ke dalam gelas beker dan ditambahkan aquades $20 \mathrm{ml}$ kemudian diaduk sampai homogen. Setelah itu, disaring memakai saringan teh untuk menyingkirkan bagian yang berukuran besar. Kemudian hasil penyaringan dimasukan kedalam tabung sentrifuge sampai $15 \mathrm{ml}$ dan sentrifuge dengan kecepatan $1500 \mathrm{rpm}$ selama 5 Menit. Tabung sentrifuge dikeluarkan dari sentrifugator dan selanjutnya diletakkan di rak tabung reaksi dengan posisi tegak lurus. Tambahkan larutan Seng Sulfat $\left(\mathrm{Z}_{\mathrm{n}} \mathrm{SO}_{4}\right)$ $33,1 \%$ secara perlahan dengan ditetesi menggunakan pipet Pasteur sampai permukaan cairan cembung. Tunggu selama 5 menit dengan tujuan memeberikan kesempatan telur cacing mengapung ke permukaaan.

Setelah itu gelas pentup, disentuhkan pada permukaan atau cairan pengapung, dan selanjutnya ditempelkan pada gelas objek. Pemeriksaan menggunakan mikroskop dengan perbesaran obyektif 40x dengan melihat morfologinya (Levine, 1990).

Data yang diperoleh disajikan secara deskriptif meliputi jenis protozoa saluran pencernaan pada monyet ekor panjang dideskripsikan dengan narasi dan tabel. Prevalensi infeksi dari protozoa pada monyet ekor panjang didasarkan pada hasil pemeriksaan ada dan tidaknya protozoa pada feses. Data yang diperoleh dipresentasikan dengan menggunakan rumus:

\footnotetext{
Prevalensi $=$

$\frac{\text { Jumlah sample yang terinfeksi }}{\text { jumlah sample yang diperiksa }} \times 100 \%$
} 


\section{HASIL DAN PEMBAHASAN}

Hasil pemeriksaan terhadap 50 sampel yang diperoleh dari populasi monyet ekor panjang di Pulau Nusa Penida terinfeksi positif protozoa saluran pencernaan sebanyak 20 sampel dengan prevalensi $40 \%$. Hasil penelitian dengan pembesaran 40x menunjukkan, terdapat dua protozoa yang menyerang populasi monyet ekor panjang di Pulau Nusa Penida yaitu protozoa Entamoeba sp, dan Balantidium coli (Gambar 1). Dilihat dari lokasi pengambilan sampel dari yang terbanyak terinfeksi yaitu di daerah Pura Puncak Mundi sebanyak 53,3\% (8 dari 15 sampel), di daerah Pura Giri Putri sebanyak 46,6\% (7 dari 15 sampel), di daerah Pura Paluang sebanyak 30\% (3 dari 10 sampel), dan terendah di Pura Saab sebanyak 20\% (2 dari 10 sampel). Untuk lebih jelas dapat dilihat pada Tabel 1. Hasil pemeriksaan sampel terhadap 50 sampel feses monyet ekor panjang di Pulau Nusa Penida menunjukan jumlah sampel positif yang terinfeksi Entamoeba sp. sebanyak 40\% (20 dari 50 sampel) dan yang positif terinfeksi $B$. coli sebanyak 32\% (16 dari 34 sampel) (Tabel 2).

Dari hasil pemeriksaan sampel feses jumlah sampel positif dengan infeksi tunggal Entamoeba sp sebanyak 4 dari 50 sampel yang diperoleh dengan prevalensi $8 \%$ dan infeksi tunggal $B$. coli sebanyak 0 dari 50 sampel yang diperoleh dengan prevalensi $0 \%$. Prevalensi protozoa dengan infeksi ganda Entamoeba sp dan B.coli jumlah sampel positif sebanyak 16 dari 50 sampel yang diperoleh dengan prevalensi $32 \%$.

Pada penelitian ini, prevalensi infeksi protozoa saluran pencernaan pada monyet ekor panjang (Macaca fascicularis) Entamoeba sp yang terdapat di Pulau Nusa Penida, Bali adalah sebesar $40 \%$, prevalensi infeksi protozoa saluran pencernaan B. coli sebesar $32 \%$ dari sampel feses yang diperiksa.
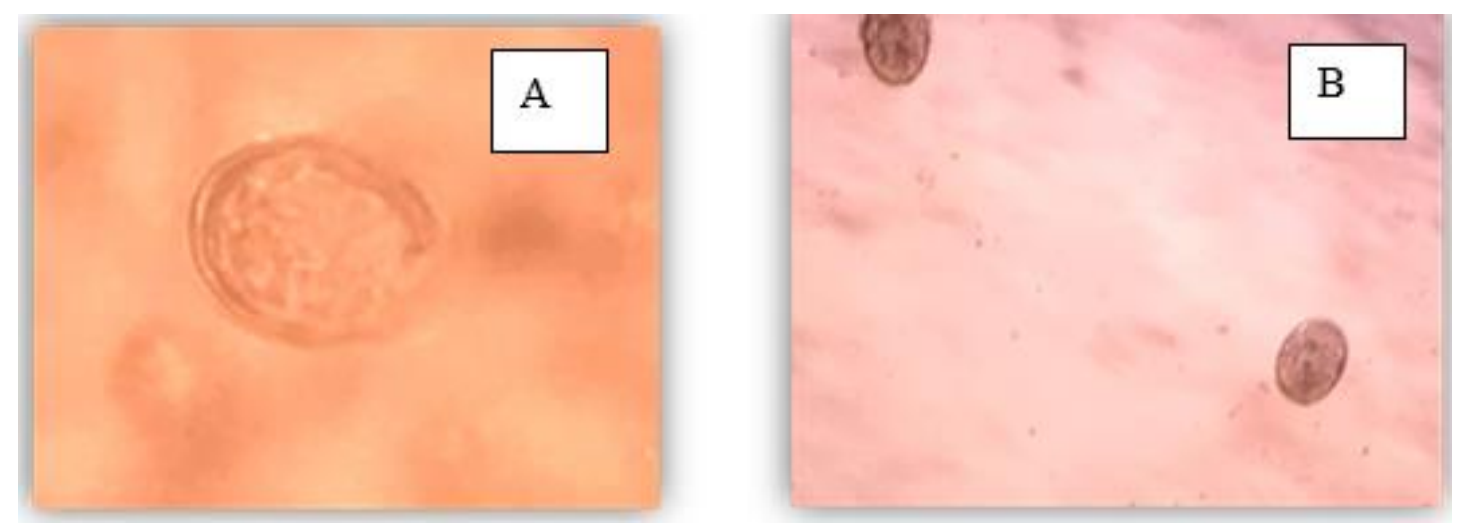

Gambar 1 Identifikasi Protozoa saluran pencernaan pada monyet ekor panjang di Pulau Nusa Penida. A. Entamoeba sp.dan B. Balantidium coli.

Tabel 1 Prevalensi Protozoa Saluran Pencernaan Pada Monyet Ekor Panjang yang Terdapat di Pulau Nusa Penida.

\begin{tabular}{lllll}
\hline No & Lokasi & $\begin{array}{l}\text { Jumlah } \\
\text { Sampel }\end{array}$ & Positif & $\begin{array}{l}\text { Prevalensi } \\
(\%)\end{array}$ \\
\hline 1 & Pura Puncak Mundi & 15 & 8 & 53,3 \\
2 & Pura Giri Putri & 15 & 7 & 46,6 \\
3 & Pura Saab & 10 & 2 & 20 \\
4 & Pura Paluang & 10 & 3 & 30 \\
\hline Total & Nusa Penida & 50 & 20 & 40 \\
\hline
\end{tabular}


Tabel 2 Prevalensi Infeksi Protozoa Saluran Pencernaan Pada Monyet Ekor Panjang di Pulau Nusa Penida.

\begin{tabular}{llllll}
\hline No & Infeksi & $\begin{array}{l}\text { Jumlah } \\
\text { Sampel }\end{array}$ & Positif & Negatif & $\begin{array}{l}\text { Prevalensi } \\
(\%)\end{array}$ \\
\hline 1 & Entamoeba $s p$. & 50 & 20 & 30 & 40 \\
\hline 2 & B. coli & 50 & 16 & 34 & 32 \\
\hline
\end{tabular}

Tabel 3 Prevalensi Infeksi Protozoa Saluran Pencernaan Pada Monyet Ekor Panjang di Pulau Nusa Penida Berdasarkan Jenis Infeksi.

\begin{tabular}{llllll}
\hline No & Jenis Infeksi & $\begin{array}{l}\text { Jumlah } \\
\text { Sampel }\end{array}$ & Positif & Negatif & Prevalensi (\%) \\
\hline & Infeksi Tunggal & & & & \\
\hline 1 & Entamoeba sp. & 50 & 4 & 46 & 8 \\
\hline 2 & B. coli & 50 & 0 & 0 & 0 \\
\hline & Infeksi Ganda & & & & \\
\hline 1 & Entamoeba dan B. coli & 50 & 16 & 34 & 32 \\
\hline
\end{tabular}

Tingkat tinggi rendahnya infeksi dari protozoa saluran pencernaan Entamoeba sp dan $B$. coli di pengaruhi dari aktifitas yang dilakukan oleh monyet ekor panjang diatas tanah. Monyet ekor panjang biasanya beraktifitas di siang hari untuk mencari makan maupun bermain dengan sesama jenisnya. Monyet ekor panjang biasa mengkonsumsi buah - buahan, daun pohon, biji - bijian dan serangga (Hadi et al. 2007). Perbedaan tingkat tinggi rendahnya infeksi protozoa saluran pencernaan pada monyet ekor panjang di Nusa Penida disebabkan oleh lokasi dari pengambilan sampel feses. Dilihat dari infeksi tertinggi penelitian yaitu di Pura Puncak Mundi bisa disebabkan dari kelembaban daerah tersebut ataupun dari tempat monyet ekor panjang mencari makan. Tempat sampah merupakan salah satu sumber dari infeksi protozoa dimana semakin banyaknya sampah akan semakin banyak protozoa atau penyakit lain yang dapat menginfeksi. Berdasarkan pengamatan di lokasi pengambilan sampel ditemukan bahwa monyet ekor panjang mencari makan di tempat pembuangan sisa - sisa persembahyangan, dimana di Pura Puncak Mundi banyaknya sampah sisa - sisa persembahyangan lebih banyak dibandingkan dengan di lokasi terendah yaitu di Pura Saab. Sumber makanan atau minuman yang terinfeksi stadium infektif dari protozoa yaitu stadium kista dapat menjadi penyebab terjadinya infeksi protozoa (Anorital dan Andayasari, 2011) pada monyet ekor panjang.

Hasil penelitian ini memperolah data yang relatif sama dengan penelitian yang dilakukan oleh Levecke et al. (2007) dimana protozoa Entamoeba sp. menginfeksi paling banyak yaitu sebesar 40\%. Levecke et al. (2007), melaporkan prevalensi protozoa saluran pencernaan monyet dan kera di kebun binatang di Belgia dengan 910 sampel feses tercatat $44 \%$ sampel terinfeksi Entamoeba $s p$. Sedangkan protozoa $B$. coli dari penelitian ini mendapatkan hasil yang lebih banyak yaitu $32 \%$ dibandingkan penelitian Levecke et al. (2007) sebanyak 13\% terinfeksi dan ditemukan sebanyak $41 \%$ terinfeksi Giardia sementara penelitian ini tidak menemukan protozoa Giardia. Beberapa penelitian mengenai prevalensi protozoa saluran pencernaan pada monyet ekor panjang telah dilaporkan seperti Ridho (2011) dalam penelitiannya pada monyet ekor panjang di kebun binatang Surabaya menemukan prevalensi infeksi protozoa $E$. histolytica sebesar 25\%, Rivera et al. (2009) melaporkan $24 \%$ terinfeksi $E$. 
histolytica dan $33 \%$ terinfeksi E. dispar dari 96 sampel yang di periksa pada monyet ekor panjang di Philipina.

Penyakit parasitik ini dapat bersifat zoonosis, menurut Rahmi et al. (2010) penyakit parasit sering menyerang monyet ekor panjang, terutama untuk monyet ekor panjang yang telah lama dipelihara atau kontak dengan manusia. Dengan terjadinya kejadian tersebut satwa liar ini dalam lingkungan manusia memungkinkan terjadinya penularan penyakit dari monyet ekor panjang ke manusia. Protozoa merupakan salah satu penyebab terjadinya penyakit pada manusia dimana entamoeba histolytica merupakan parasit penyebab amebiasis usus dan hepar (Maryatun, 2008) dan balantidium coli menyebabkan disentri, sakit perut, dan turunnya berat badan (Gupta, 2017).

Di lokasi penelitian ini, masyarakat masih menerapkan pola hidup yang kurang sehat, seperti masih sedikit tersedianya WC di setiap rumah dan kurangnya self hygine, sedangkan penyebaran dari hewan ke manusia dapat disebabkan karena pola hidup masyarakat yang kurang higienis seperti mengkonsumsi buah - buahan langsung tanpa dicuci terlebih dahulu dan jarang memakai sandal jika bepergian. Jadi penyebaran protozoa saluran pencernaan Entamoeba sp. dan B. coli dari manusia ke hewan dan sebaliknya bisa saja terjadi walaupun belum ada laporan terkait kasus ini.

\section{SIMPULAN}

\section{Simpulan}

Penelitian yang dilakukan menemukan prevalensi infeksi protozoa saluran pencernaan pada monyet ekor panjang sebesar $40 \%$. Jenis protozoa yang ditemukan adalah protozoa Entamoeba $s p$ sebesar $40 \%$ dan Balantidium coli sebesar $32 \%$ pada populasi monyet ekor panjang di Pulau Nusa Penida.

\section{Saran}

Protozoa yang ditemukan pada monyet ekor panjang di Pulau Nusa Penida memiliki potensi zoonotik sehingga perlu penanganan yang serius dengan menerapkan praktek higiene dan sanitasi yang baik kepada masyarakat sekitar, serta perlu dilakukannya penelitian lebih lanjut untuk mengetahui jenis penyakit lain yang mungkin menginfeksi monyet ekor panjgang di Pulau Nusa Penida.

\section{UCAPAN TERIMAKASIH}

Penulis mengucapkan terima kasih utamanya kepada Laboratorium Parasitologi Veteriner Fakultas Kedokteran Hewan, Universitas Udayana dan semua pihak yang telah membantu dalam penyelesaian penelitian ini.

\section{DAFTAR PUSTAKA}

Anorital, Andayasari L. 2011. Kajian epidemiologi penyakit infeksi saluran pencernaan yang disebabkan oleh amuba di Indonesia. Media Lubung Kesehatan. 21(1): 1-9.

Burgos-Rodriguez A. 2011. Zoonotic disease of primate. Vet. Clin. Exot. Anim. 14: 557-575.

Gupta S, Bharati P, Sinha KP, Shrivasta RK. 2017. Balantidium coli: Rare urinary pathogen or fecal contaminant in urin? Case study adn review. $J$. Dental Med. Sci. 16(3): 88-90.

Hadi I, Suryobroto B, Perwitasari FD. 2007. Food preference of semiprovisioned macaques based on feeding duration and foraging party size. Hayati J. Biosciences. 14(1): 1317.

Joesoef JA, Sajuthi D, Wijaya A, Saban MUE. 2018. Keragaman endoparasit pada macaca fascicularis dan potensi zoonotiknya dengan cuaca berbeda di Kota Kupang. J. Vet. 19(4): 451-459.

Levecke B, Dorny P, Geurden T, Vercammen F, Vercruysse J. 2007. Gastrointestinal protozoa in non-human primates of four zoological gardens in Belgium. Vet. Parasitol. 148: 236-246.

Levine ND. 1990. Buku Pelajaran Parasitologi Veteriner. Gadjah Mada University Press. Yogyakarta. 
Mahayuni NPK, Watiniasih NL, Yusup DS. 2018. Populasi dan perilaku kera ekor panjang (Macaca fascicularis) di Desa Pancasari Sukasada Buleleng Bali. J. Simbiosis. 6(1): 12-15.

Maryatun. 2008. Entamoeba histolytica: Parasit penyebab amebiasis usus dan hepar. J. Kedokteran Syiah Kuala. 8(1): 39-46.

Nugraha EY, Wandia IN, Soma IG. 2018. Variasi genetik populasi monyet ekor panjang (Macaca fascicularis) di Pulau Nusa Penida, Klungkung, Bali. J. Vet. 19(4): 531-538.

Rahmi E, Hanafiah M, Sutriana A, Hambal M., Wajidi F. 2010. Insidensi Nematoda Gastrointestinal dan Protozoa pada Monyet Ekor Panjang (Macaca fascicularis) Liar di Taman Wisata Alam (TWA) Pulau Weh Sabang. J. Ilmiah Ilmu-Ilmu Peternakan.13(6): 286-291.
Ridho H. 2011. Prevalensi Protozoa Saluran Pencernaan pada Monyet Ekor Panjang (Macaca Fascicularis) Melalui Pemeriksaan Feses di Kebun Binatang Surabaya. Skripsi Sarjana Kedokteran Hewan, Universitas Airlangga

Rivera WL, Anthony J, Yason DL, Edric D, Adai V. 2009. Entamoeba histolytica and Entamoeba dispar infection in Captive Macaques (Macaca fascicularis) in the Philippines. Japan Monkey Centre and Springer.

Supriatna J, Wahyono EH, 2000. Panduan lapangan: Primata Indonesia. Jakarta: Yayasan Obor Indonesia.

Toft JD, Eberhard ML. 2012. Nonhuman primates in biomedical research diseases $2^{\text {nd }}$ Ed. Bennet BT, Abee CR, Tardif S, Morris T, editor. Kanada (US): Academic Press.

Yulfi H. 2006. Protozoa intestinalis. Skripsi. Universitas Sumatera Utara. Repository. Medan. 